Peripatopsis, etc." ; Phil. Trans. Roy. Soc., B, 233, No. 606 ; pp. 483-580; London: Cambridge University Press, $1949 ; 40 s$.) lies in the presentation of the facts based on a plentiful supply of material mainly from four species of Peripatopsis, namely, $P$. balfouri, $P$. sedgwicki, $P$. moseleyi and $P$. capensis obtained from living animals in the laboratory and dealt with by up-to-date methods. The second interest of the work arises from the utilization of the data so obtained to discuss the problems related to the Onychophora and to other groups. In the former, support is given to Sedgwick's suggestion that lack of yolk in viviparous forms is secondary; there is no evidence to support the suggestion that the lips of the 'mouthanus' contribute to mesoderm formation, nor any indication of primary and secondary metamerism, nor of the presence of a pre-antennal segment. The observations allow of a full and interesting discussion of the segmentation of the anterior end and the relationship between this and the segmentation of the similar parts of Annelida and higher Arthropoda. No support is found for the interpretations associated with the names of Ferris and Hanke in the former, nor of Snodgrass in the latter.

\section{Diseases and Cytology of the Amaryllids}

AMONG the many interesting papers on floristic and geographical aspects of the Amaryllidacer appearing in Herbertia for 1948 are two contributions of specialist interest (Vol. 15. Stanford, Calif. : American Plant Life Society, 1949 ; n.p.). Philip Brierley describes several diseases of Amaryllids, excluding those of Allium and Narcissus. Red leaf spot and virus diseases appear to be the chief troubles. The former is caused by the fungus Stagonospora curtisii, which first produces round red spots on leaves, flower stalks and petals. These later coalesce to form larger cankers with fructifications of the fungus in the centre. Iied leaf spot is bulb-borne, and may be controlled by soaking dormant bulbs in formalin solution $(1: 200)$ for two hours. Mosaic disease is the principal virus trouble; it is not seedborne, and more information on the means of natural transmission is needed. Several other diseases of minor importance are mentioned more briefly. Frnesto de Miranda Neto reports from Brazil that Amaryllis calyptrata and $A$. stylosa appear to be normal diploids with $2 n=22$ chromosomes; $A$. regince $(2 n=33)$ is regarded as a hybrid between a species with 22 chromosomes and one with 44 .

\section{Wool Industries' Research Association : Annual Report}

THe report of the Director of Research of the Wool Industries' Research Association for 1948-49 (Publication 188, Leeds, 1949) records some progress with the building programme and evidence of industrial experimentation and inventive activity in the combing, drawing and spinning sections of the worsted industry. The main work of the Operationa] Research Section has been concerned with faults in worsted yarns, and recommendations to help reduce the incidence of the faults are now being investigated. Two papers on the theory of drafting and one on sequential analysis have been prepared. Fundamental scientific studies have continued to be concerned chiefly with the mechanical properties of the wool fibre, such as the coefficient of thermal expansion of horn keratin and the bending fracture of single fibres, the electrical properties of wool, the products of enzymatic hydrolysis of wool, the setting of wool fibres, the investigation of the cystine peptides in partial hydrolysation of wool and oxidized wool. Biological research has included fleece studies on Romney and Blackface wool, and technological studies of combing oils, woollen oils and waterproofing have continued.

\section{Archæological Records in South Australia}

A RECENT issue of the Records of the South Australian Museum (7, No. 4) contains articles on "The Cowries of Fiji", "Two Sand-dwelling Cumacea", "A New Australian Shark", and on Astacopsiphagus parasiticus, and two articles of archæological interest : one, "Large Stone Implements from South Australia" by H. M. Cooper, and the other, "Some Aboriginal Camp Sites in the Woakwine Range Region of the South-East of South Australia", by T. D. Campbell and H. V. V. Noone. Both are largely catalogues of material, but are important as such. The problem in Australia is the dating of the Stone Age sites. Whether, as suggested, correlation with recent raised beaches will be possible or yield certain results remains to be seen. In the meantime, description of finds made and their comparison with other Australian material would seem to be the right procedure.

\section{Immigration into the United States}

THE general subject of immigration into the United States is considered in the volume entitled "Reappraising our Immigration Policy", which is edited by Dr. Hugh Carter (Ann. Amer. Acad. of Political and Social Science, 262 ; March 1949). The. title is misleading, however, as the articles making up the issue are factual in character, and no attempt is made to examine critically the foundations or future of American immigration policy. The contributions fall into four parts dealing respectively with the historical aspects of immigration, demographic factors, assimilation and current immigration problems. While the issue contains little that is new to the specialist, the general reader who wishes to obtain information about immigration to the United States will find it a useful compendium.

\section{Plastics Industry in Germany}

THE journal Kunststoffe, published by Karl Hanser, of Munich, is now entering on its fortieth year. Since its beginning this journal has been able to record the successive stages in the development of the now very important plastics industry. It was founded in 1910 by Dr. Richard Escales and deals with all aspects of the industry. One of the oldest plastics was celluloid (1870); 'Bakelite' appeared in 1909, and the many new polymer products began about 1928 . The annual production of plastics in Germany is now about 100,000 tons with a value of 300 million D.M., that of the finished products being about double. All those interested in the plastics industry will no doubt be pleased to know that this old-established publication is still flourishing.

\section{Science Service, Washington : Election of Trustees}

At the annual meeting of Science Service, Inc., held in Washington, D.C., on April 27, the following were re-elected as trustees for a three-year term : Prof. R. A. Millikan, professor emeritus, California Institute of Technology; Prof. Ross G. Harrison, Sterling professor emeritus of biology, Yale University; O. W. Riegel, director of the Lee School of Journalism, Washington and Lee University (treas- 